Tимур Бочаров

\title{
ПРАВИЛА, ВРЕМЯ И НАСИЛИЕ В КАЗАРМЕ: ЛОГИКА ТОТАЛЬНОГО ИНСТИТУТА В ПЕРЕХОДНЫЙ ПЕРИОД
}

В статье анализируется повседневная жизнь российской армии. В рамках теории тотальных институтов Эрвина Гоффмана обычно выделяют такие признаки социального порядка в армии как дихотомия формальных и неформальных правил, особая организация времени, высокий уровень насилия. В отличие от подобных исследований в статье рассматриваются правила, время и насилие не как внешне заданные характеристики, а как результат языковых практик и интерпретаций самих обитателей казармы. Подобная динамичная перспектива помогает понять, почему феномен дедовщины сохраняется в армии, несмотря на изменения институциальной среды. В частности, в исследовании показывается неразрывная связь формальных правил устава и неформальных правил дедовщины, которые в определенных ситуациях являются сторонами одной медали. Особое внимание уделяется тому, как изменение военной формы способствует выстраиванию символических границ и воспроизводству статусной иерархии в армии. Далее описываются социальные практики солдат, которые позволяют материализовывать время и делать его властным ресурсом. С переходом с двухлетнего на однолетний срок службы эти практики претерпели изменения, но продолжают сохранять свое значение. Наконец, предлагается ответ на вопрос, почему многие действия, однозначно воспринимаемые во внешнем мире как насильственные, не видятся таковыми в армии. Кроме того, анализируется роль в трансформации казарменного насилия видеокамеры смартфона, постепенно становящейся атрибутом армейской жизни. В частности, показано как факт видеосъемки зачастую определяет происходящее. В основу исследования легли наблюдения автора в период прохождения срочной службы, рассказы знакомых и случайных собеседников об этом, материалы армейских

Тимур Юрьевич Бочаров - магистр социологии (Европейский университет СПб), магистр права (Манчестерский университет), аспирант (Кентский университет), научный сотрудник Института проблем правоприменения ЕУ СПб, Санкт-Петербург, Россия. Электронная почта: tbocharov@eu.spb.ru 
форумов. Для лучшего понимания специфики российской дедовщины предлагаются кросс-культурные сравнения с внешне схожим французским феноменом bizutage периода призывной службы.

Ключевые слова: тотальный институт, армия, дедовщина, Эрвин Гоффман, Эвиатар Зерубавель, Рэндалл Коллинз

DOI: 10.17323/727-0634-2019-17-3-359-374

Возвратившемуся из армии человеку часто задают вопрос, как следует повести себя на срочной службе. Вопрос обычно вызывает затруднения, поскольку отвечающему сложно сформулировать общую модель поведения, ответ будет неизбежно уходить в конкретные примеры. Примечательно, что социологическое мышление таких затруднений не знает. Социальный порядок в закрытых учреждениях чаще всего описывается с помощью модели «тотального института» Эрвина Гоффмана (Goffman 1961). Применяя теорию Гоффмана к казарменной жизни, обычно выделяют такие ее характеристики, как дихотомия формальных и неформальных правил, особая организация времени, воспроизводство отношений насилия и доминирования (See, Zurcher 1965; Cernikova 2004; Пэнто 2001). Однако упускается из виду, что сами жители казарм обладают способностью описывать и объяснять условия своего места обитания (придавать им «практический смысл»), в то же время ориентируясь на эти описания-объяснения в своих действиях. В статье анализируются правила, время и насилие в казарме именно как результат практик ее обитателей, а не внешне заданные условия.

Особую актуальность этот вопрос имеет в связи с последними изменениями в армии. Если о «классической» дедовщине советского периода и 1990-х гг. написан ряд работ, то повседневность современной казармы малоизучена. Десять лет назад срок службы был сокращен до одного года, что рассматривалось в качестве одного из способов покончить с дедовщиной, как казалось, завязанной на двухлетнем периоде. Следование уставу теперь жестче контролируется, проверки военной прокуратуры и телесные осмотры стали частым явлением в воинских частях. Новые технологии в виде смартфонов проникают в армейскую жизнь, позволяя фиксировать происходящее на фото или видео, общаться с внешним миром («гражданкой»). Но несмотря на все изменения, практики дедовщины не исчезают, хотя и модифицируются. За счет чего достигается эта адаптация практик к новым условиям?

В теории практик вопрос о том, как они меняются, является одним из центральных (Волков 1997). На примере дедовщины можно заключить, что эти изменения никогда не случаются сами по себе: это всегда результат действий акторов по определению тех или иных практик в качестве соответствующих (все еще) или несоответствующих (уже) дедовщине с учетом меняющегося контекста. Об универсальности феномена дедовщины говорить нельзя; даже в ранние периоды ее понимание сильно варьировалось по родам войск и ре- 
гионам (Oleynik 2004). Лучше всего специфика повседневных практик усваивается на кросс-культурных контрастах (Хархордин 2008), поэтому в статье будут встречаться отсылки к французскому явлению bizutage периода призывной службы (до 2001 г.), ошибочно отождествляемому с дедовщиной.

\section{Практическая компетенция как предмет и метод исследования}

В основе статьи лежат мои наблюдения в период срочной службы с 2010 по 2011 гг, но их трудно назвать «включенным наблюдением» в строгом смысле. Последнее предполагает формальные процедуры сбора данных, которые мною не осуществлялись, т.к. не ставилась цель исследования. Однако призыв в армию позволил приобрести практическую компетенцию солдата-срочника. Гоффман в своем единственном рассуждении о полевой работе, формулирует максиму: хотя исследователь может покинуть поле, он должен действовать так, как если бы не мог (Goffman 1989: 125). Это сильная максима, но для хорошего исследования ее недостаточно: мало действовать так, как если бы у тебя был практический интерес к изучаемому полю, хорошо бы действительно иметь его. Армия с ее отсутствием свободного выхода предоставляет такую возможность. Таким образом, главным методом исследования стала приобретенная практическая компетенция.

«Метод» здесь понимается как обыденное наблюдение и описание социального порядка. Социолог должен стать таким же компетентным носителем практики, которую он описывает, как и сами практикующие. Приобретенная компетентность выступает не только методом, но и самим предметом исследования. Как пишет по этому поводу Гарольд Гарфинкель, компетентность является «рефлексивной составляющей «работы», на которую данная компетентность направлена» (Garfinkel 2002: 167). Хорошее описание практик в идеале учит тому, как осуществлять эти практики. Автор не просто знакомит читателя с описываемыми ситуациями, а дает общее понимание того, как действовать в сходных ситуациях, т.е. делится умением «продолжить ряд». Описания ниже направлены преимущественно на это. В основу исследования легли также нарративы знакомых и случайных собеседников о своем опыте службы, материалы армейских форумов.

\section{Правила и язык:}

\section{жизнь по уставу vs жизнь по дедовщине}

В казарме, как новобранец, так и старослужащий часто сталкиваются с ситуациями, когда необходима работа по формулировке правил для обоснования своих действий. Например, старослужащему на распределительном пункте поручают организовать уборку в расположении новобранцев. Перед ним встает задача: как распределить между новобранцами обязанности, 
учитывая, что уборка туалета является работой с низким статусом, и это призывникам понятно даже в первый день службы. В воинской части уборка туалета обычно ложится на плечи дневальных, в которые попадают после того, как «деды» и офицеры уже присмотрелись к молодым и определили, к какой службе они годятся. В данной ситуации старослужащий этим временем не располагает, призывников он видит впервые, но ему надо быстро принять решение и мотивировать его. Для этого формулируется in situ правило: на непопулярные работы отправятся те, кто не успел позаботиться о стрижке волос наголо в военкомате, тем самым в первый же день показав себя нерасторопными «воинами» (частое пейоративное обращение старослужащих к новобранцам).

В другой ситуации, «дух» ${ }^{1}$ может попасть в наряд по столовой, где его обязанность состоит в раздаче пищи. Обычно на обед готовятся два блюда: менее привлекательное - скажем, «болты» (перловая каша) и более привлекательное - например, картофель с тушеной капустой. Каждый «дед» считает своим долгом подойти за второй, а порой и третьей порцией варианта обеда № 2, что считается его правом, положенным по сроку службы. Если раздающий будет следовать этому правилу дедовщины и накладывать каждому «деду» по добавочной порции, он быстро столкнется с проблемой: пища в баке закончится и старослужащим, прибывшим позднее, может не достаться даже одной порции. В этом случае он вынужден заниматься сортировкой очереди и периодически делать исключения из общего правила, определяя ad hoc, кому из «дедов» можно отказать в добавке, а также решая какую формулировку предложить: вот-вот придет дежурный офицер с проверкой, авторитетный старослужащий просил оставить блюдо и т.п.

В концепции Гоффмана разрыв между формальными правилами персонала и неформальными правилами обитателей является характеристикой тотальных институтов. Поэтому исследования армии почти всегда фокусируется на двух уровнях правил (см.: Пэнто 2001:26): правилах устава и правилах дедовщины. Однако дедовщину менее всего следует представлять в качестве набора правил, скорее, это способность идентифицировать различные ситуации как следование правилам дедовщины либо как нарушение этих правил. Эта идентификация - языковая и производится с помощью часто употребляемой в армии и открытой для интерпретаций категории «положено» (Подрабинек 1991: 195). Ограниченный набор запретов для молодых типичен в большинстве частей: не положено сидеть на кровати, держать руки в карманах, опираться о стенку, курить вне курилки, разговаривать во время приема пищи, уносить еду из столовой. Однако особенность категории «положено»

\footnotetext{
${ }^{1}$ В зависимости от стадии службы существуют следующие ступени: «дух», «слон», «череп», «дед», «дембель» (названия могут варьироваться в разных войсках и регионах). С переходом на один год службы эта система где-то трансформировалась в более простую формулу «полгода - дух, полгода - дед», где-то сохранилась, но в сжатом виде. Однако даже в двухлетний период многоступенчатая модель могла осознанно сокращаться (Банников 2002).
} 
состоит в том, что она всегда может быть применена старослужащими по ситуации. Например, перед отбоем умывальная комната всегда забита народом, т.к. все стараются успеть почистить зубы и умыться перед сном. Простым практическим решением для «дедов» будет объявить прибывшим молодым, что пользование двумя крайними раковинами им не положено, такова здесь традиция. Но в случае прибытия внеочередной партии призывников, когда умывальная комната переполняется еще больше, «традиция» уже включает задним числом три или более умывальников под запретом. С одной стороны, процесс умывания становится удобнее для «дедов» (не надо лишний раз отгонять молодых), с другой стороны символически подчеркивает границу между статусными группами (сродни сегрегации).

Распространенной является попытка определить дедовщину через противопоставление воинским уставам. Это видение воспроизводится в уголовном законодательстве, где соответствующие практики определяются как неуставные взаимоотношения между военнослужащими. Однако грань между уставом и дедовщиной не является четкой, во многом они стороны одной медали. Особенно ярко это прослеживается в том, как следование уставным правилам ношения формы новобранцами оборачивается конститутивной частью практик дедовщины. Так, манипуляции с формой положено производить лишь после строго определенного периода службы. Во французской армии также существовала разница во внешнем виде молодого (bleu) и старика (ancien). Однако она была не механизмом дедовщины, а скорее вопросом наличия или отсутствия практических навыков: со временем новобранец узнавал, как можно сгладить малопривлекательные черты уставной формы. Как описывает французский писатель Даниэль Пеннак, выросший в семье гарнизонного офицера:

...после всевозможных обменов с товарищами необходимо еще уменьшить размеры гигантского берета, который смотрится как пирог, с помощью вымачивания в пиве в течение нескольких дней. Получается стильный и крошечный берет, который носится на макушке черепа, сообразно обстоятельствам и производимому эффекту. Если форменная гимнастерка слишком длинна, она подгибается настолько, чтобы были видны ягодицы, которые подчеркиваются подтягиванием брюк к талии с помощью брючного пояса. Ремень опускается существенно ниже пупка, таким образом, чтобы туда можно было просунуть большие пальцы рук, для создания видимости опасной и равнодушной манеры держаться бывалого вояки, остающегося на высоте в любых ситуациях (Pennac 1973:94-95).

Как подмечает Олег Лысенко, максимально непрезентабельная советская (российская) военная форма обеспечивала неиссякаемый простор для проведения статусных различий:

С одной стороны, старослужащему было весьма трудно увильнуть от следования вестиментарным правилам, предписанным его призыву 
(«Ты чего ходишь, как молодой?»), а с другой - старослужащие сами поддерживали статусный символизм формы, не допуская проникновения неуставных элементов в среду «молодых бойцов»- то, что можно дедушке, нельзя молодым (Лысенко 2012).

В российской армии «духу» по дедовщине положено носить форму в полном соответствии с уставом: сильно затянутый ремень, все пуговицы кителя застегнуты. Головной убор носится не выше, чем на 2 пальца от бровей, китель и бушлат сзади не должен иметь складку на сторону («галочка»). Внешний вид «слона» не сильно отличается, только ремень дозволяется немного ослабить. Однако «череп» уже во всем походит на «деда», он не ограничивает себя уставом. Верхняя пуговица расстегнута, ремень полностью расслаблен, пряжка ремня («бляха») выпрямляется ударами о твердую поверхность, на кителе или бушлате сзади делается складка по талии (направо - осенний призыв, налево - весенний). Воротник кителя отглаживается до стоячего положения («стойка»), подворотничок пришивается не уставной, а самодельный из простыни, головной убор носится почти на макушке. Тем не менее в отсутствие прямых запретов на манипуляции с одеждой критическую важность приобретают тонкие ситуативные различия между «дедом» и внешне похожим на него «черепом». Например, несмотря на право «черепа» выпрямить пряжку своего ремня, ее чрезмерное выпрямление до идеальной плоскости («прямая дорога домой») может встретить недовольство «дедов» в связи с несвоевременностью.

\section{Локальный темпоральный порядок}

Феномен дедовщины не может быть понят без учета темпорального измерения. Если привилегии положены старослужащим, то они положены им ipso facto, по сроку службы. Какие-то особые заслуги здесь не требуются, само прожитое время становится властным ресурсом. В работе по социологии времени Эвиатар Зерубавель, ученик Гоффмана, немалое внимание уделяет социальной организации времени в тотальных институтах - госпитале и бенедиктинском монастыре (Zerubavel 1985). Он описывает обыденные представления о времени как когнитивные ожидания, которые носят неявный характер для их носителей, неслучайно уже в заглавии он ведет речь о «скрытых ритмах». Однако применительно к армейскому быту социальное время правильнее рассматривать как наблюдаемые практики, а не скрытое когнитивное измерение.

Компетенция солдата включает способность распознавать и описывать такие практики, в каком-то смысле «материализовывать» время. Он узнает, что и когда ему положено, как считать время до дембеля, как повести себя в определенный период службы, чтобы не осложнить жизнь в последующие. Как упоминалось выше, в армии существуют статусы, привязанные ко времени службы: «дух», «слон», «череп», «дед». Перевод из одной стадии 
в другую производится ударами солдатского ремня по ягодицам переводимого, лежащего плашмя (где-то упирающегося в четыре ножки перевернутого табурета): 6 ударов - перевод в «слоны», 12 ударов - в «черепа». Переход в категорию «деда» происходит либо вообе без ритуала, либо с его символическим оформлением - молодой ударяет деда вместо ремня ниткой, а последний «кричит» от боли. Все переводы привязаны к началу «сотки», т.е. стодневному периоду до выхода приказа об увольнении в запас. Потенциальный «слон» выбирает себе «деда», который его переводит и которому он «тянет сотку», что подразумевает оказание различных мелких услуг, обеспечение сигаретами и продуктами в этот период.

Однако важнейшая вассальная обязанность - учет времени, оставшегося «деду» до приказа. Каждый день после ужина слон объявляет «деду» с преамбулой «разрешите доложить, сколько дедушке служить» искомое количество дней и вручает сигарету, на которой надписана эта цифра. Объявление неверной цифры является серьезным «залетом» (проступком), за которым с большой вероятностью последует какое-нибудь наказание. В некоторых частях также подписывается и количество дней непосредственно до отъезда домой. При «веселом» настроении «деда» такое расхождение в способах счета иногда может быть поводом приписать слону «залет». «Слон» называет дни до приказа, «дед» недоволен, потому что это не окончательный срок, когда он точно попадет домой - неизвестно. «Слон» называет дни до увольнения в запас, «дед» тоже недоволен, потому что дней в этом случае на порядок больше и ожидание тягостнее. Разумным будет держать две цифры в уме и при случае называть их обе сразу. Практика счета дней включает также и умение вовремя распознать попытки «дедов» подловить на невыполнении обязанности. На любой неожиданный вопрос, который подразумевает ответ в числовом виде («сколько дверей в казарме?», «номер пожарный машины?»), «слон» должен быть готов назвать количество дней, оставшихся «деду». ${ }^{1}$ Самому «слону» считать свои дни категорически запрещается.

Если мы обратимся к французскому случаю, то увидим, что право вести учет дней до дембеля (peter son score) необходимо заслужить сроком службы. Каждый «старик» во французской армии носил маленький календарь, где вел счет времени до дембеля, прокалывая прошедшие дни иглой. Объявление своего счета использовалось как заместитель приветствия: при встрече один здоровался своей цифрой, второй отвечал своей (Bessin 2002: 88). Дни в этом случае именовались 'jus' аналогично наименованию кофе низкого качества, входивший в ежедневный завтрак французского срочника (Cassagne 2007: 255). Выпил утром дежурную

\footnotetext{
${ }^{1}$ Во французской казарме старики также практиковали загадки, связанные со счетом дней до дома, но их практической целью было скорее продемонстрировать превосходство и создать повод для смеха, нежели подловить молодого на нарушении правила с последующим наказанием (Daunizeau 2002: 80-81).
} 
чашку кофе, значит еще один день можно вычеркнуть из числа оставшихся до дома. Молодым называть свои цифры вслух было запрещено.

Первый день «сотки» в России знаменуются традиционным бритьем голов «дедов» под ноль, что влечет ответные санкции со стороны офицеров. Подобная реакция ожидается, в этом и состоит символический смысл данного действия, что выявляется в коллективном обсуждении накануне вопроса брить или не брить голову («злить шакалов ${ }^{1}$ или нет»). Высокая удельная доля обритых голов на построении призвана показать, что в части до сих пор живут по дедовщине, тянут сотку и отмечают ее начало. При этом формального нарушения устава нет, поскольку нигде не оговорена конкретная длина волос военнослужащего, что еще раз показывает ошибочность понимания дедовщины через противопоставление уставу ${ }^{2}$. Несмотря на это, подобные действия трактуются офицерами как проявление дедовщины, в связи с чем следует наказание: отправка на работу без молодых, а значит и без возможности переложить на них работу, внеплановая строевая подготовка или марш-бросок.

\section{Повседневное насилие и видеокамера}

В качестве особенности российской дедовщины по сравнению с практиками инициации в других армиях исследователи отмечают высокий уровень насилия. В частности, на этом делают акцент составители доклада Human Rights Watch, посвященного проблеме дедовщины (Human Rights Watch 2004). Однако в этом и других исследованиях не раскрывается в полной мере вопрос, почему насилие по-разному воспринимается внутри и снаружи казармы. В российской казарме насильственные практики в отношении новобранцев могут осуществляться в различной форме, рукоприкладство играет далеко не первую роль. Весь комплекс действий, связанных с принудительным созданием для новобранца тяжелых условий, принято обозначать понятием «задрочить» ${ }^{3}$. Можно «задрочить» с отсылкой к уставу (подъем и отбой за 45 секунд, «вспышка слева/справа», строевая подготовка);

\footnotetext{
1 «Шакал»- офицер на армейском жаргоне.

2 Прическа военнослужащего, усы, если они имеются, должны быть аккуратными, отвечать требованиям гигиены и не мешать использованию средств индивидуальной защиты и ношению снаряжения. Устав внутренней службы ВС РФ: ст. 334 (Указ Президента Российской Федерации 1993).

3 «Вспышка слева/справа» - по этой команде необходимо отпрыгнуть в противоположную сторону и лечь на землю, сгруппировавшись. «Полтора» - положение на полусогнутых ногах (в процессе приседания) или руках (в процессе отжимания) до отмены команды. «Ловля бабочек» - прыжки с хлопком над головой. «Спутник» - «дед» находится в движении, молодой бегает вокруг него, стараясь не задеть. «Сушка крокодила» - положение, когда руки упираются в передние дужки койки, ноги в задние. «Щетка»-процесс мытья пола с чрезмерным количеством мыльной пены.
} 
«прокачкой» («полтора», «ловля бабочек»); казарменными играми («спутник», «сушка крокодила»); уборкой помещения («щетка»). Для этих целей сгодится любая подходящая ситуация. Например, с началом «сотки» «дедам» по традиции полагается отдавать все свое сливочное масло на завтраке молодым. Обычно это преподносится как акт доброй воли и забота о своих «слонах», тогда последние сами определяют, сколько масла они хотят и готовы съесть. Однако при желании «деды» могут превратить этот ритуал в очередной способ «вздрочнуть слона» (особенно если тот приступает к еде с излишним рвением) - его заставляют съесть все имеющиеся в наличии порции масла «дедов», что может обернуться расстройством желудка.

Если применяется физическое воздействие, то оно обычно облекается в устойчивую форму с последовательностью действий и комментариев («фанера» ${ }^{1}$, «лось»²). Сама упорядоченность действий позволяет участникам увидеть не спонтанный акт агрессии, но следование традициям дедовщины, т.е. понятное действие, исходя из внутренней казарменной логики. Силовой отпор начинает выглядеть уже неуместной реакцией на ситуацию, вне зависимости от наличия решимости к этому у молодых солдат, а также их количества по сравнению со старослужащими.

Во французской призывной армии существовала традиция издевательств 'les brimades'. Например, так выглядел ритуал «ярмарка скота» (foire aux bestiaux): утром выстраивается в шеренгу группа прибывших новобранцев и разыгрывается сцена осмотра скота на рынке, проверяются зубы и крепость сложения. Если какой-то новобранец краснел, то старики дружно смеялись и объявляли такое «животное» непригодным для хозяйства (Bozon 1981: 124). Здесь имеется игра слов: одна из болезней домашнего скота называлась во Франции того времени 'maladie rouge' (от фр. красная болезнь). Однако все эти действия совершались обычно лишь в первые дни службы, когда больше всего поводов для глумления над неопытностью. В российской казарме, напротив, в первые дни службы до принятия присяги прибывших вообще не принято трогать, поскольку те считаются еще «запахами», т.е. как бы вовсе не существуют и не могут быть пока даже объектами насильственных действий в отличие от «духов».

Рэндалл Коллинз строит микросоциологическую теорию, способную дать общую рамку разнообразным проявлениям насилия (Collins 2008). Вслед за Гофманом, чьим студентом он являлся, Коллинз берет в качестве элементарной единицы анализа ситуацию. Пошаговое наблюдение ситуации насилия по Коллинзу позволяет избежать ангажированных оценок, мифов

\footnotetext{
${ }^{1}$ Серия ударов по груди с ритуальным обменом репликами (см.: Ефимов 2005).

2 «"На лося!" - орет кто-нибудь, замахиваясь кулаком. Скрещиваешь запястья и подносишь тыльной стороной ко лбу. В образовавшиеся "рога" получаешь удар. Опускаешь руки и говоришь: "Лось убит! Рога отпали! Не желаете повторить?" Если желают, все повторяется» (Чекунов 2008).
} 
и идеализаций, характерных для обыденного дискурса насилия. Он критикует концепцию «символического насилия» Пьера Бурдье. Если физическое насилие имеет, по мнению Коллинза, референта в реальной жизни и может быть изучено, то символическое насилие у Бурдье является абстрактным и оценочным понятием. Использование последним термина «насилие», имеющего негативные коннотации, вызвано скорее желанием подкрепить критический тезис о том, что ряд социальных практик морально нелегитимны (Collins 2008:24-25). Коллинз так резюмирует разницу: ««Символическое насилие» - это просто теоретическая игра слов; воспринимать ее буквально будет сильным недопониманием природы реального насилия. Символическое насилие дается легко; реальное насилие - тяжело» (Collins 2008: 25).

Как кажется, между теориями Коллинза и Бурдье нет принципиального различия. Коллинз трактует физическое насилие как объективную и доступную анализу социолога реальность, в отличие от кажущегося ему эфемерным символического насилия. Однако в случае с насилием мы имеем дело с объективностью социального факта, которая производится самими участниками взаимодействий, реальность/нереальность не должна постулироваться социологом. Насилие как социальный феномен подразумевает, что некоторые акты осознаются как насильственные практики в том или ином контексте, люди ориентируются на них соответствующим образом. Поэтому вполне возможны конфликтующие интерпретации одних и тех же действий. В качестве иллюстрации можно привести громкий случай, произошедший в Памплоне (Испания), когда суд в 2018 г. осудил группу молодых людей за домогательства, а не сексуальное насилие, исходя из того, что на видеозаписи девушка не оказывала сопротивления. Это вызвало волну протестов, целью которых было переопределение событий именно как «насилия», в противоположность трактовке суда. Одним из главных лозунгов на транспарантах был ’No es abuso, es violación’ («Это не домогательство, это изнасилование»). Такой ракурс помогает понять, почему многие практики не воспринимаются в армии как насилие, хотя со стороны видятся таковыми. Например, вернемся к описанной выше практике перевода из «слонов» в «черепа». Она состоит в том, что «дед» бьет своего «слона» ремнем с тяжелой металлической пряжкой, после чего в качестве «поздравления» могут добавить удары остальные «деды». Это одно из наиболее болезненных действий, которое претерпевает солдат, но оно не воспринимается в качестве насилия в локальном контексте казармы. Важно отметить, что это не столько субъективное самовнушение «жертвы», сколько общее понимание ситуации (скажем, степень соответствия формы гематом барельефной звезде на пряжке ремня может быть поводом для веселых обсуждений и шуточной бравады в первый банный день после перевода).

Теоретическая позиция Коллинза отчасти обусловила и его методологические предпочтения. Свидетельствам самих акторов он не слишком доверяет: «Когда участники рассказывают о ситуациях насилия, они склонны 
давать очень усеченные и, в соответствии с их собственным пониманием, идеализированные версии произошедшего» (Collins 2008: 4). Привилегированным источником для него являются видеозаписи ситуаций насилия, позволяющие секунда за секундой анализировать эмоции, мимику и жесты сторон конфликта. В этом Коллинз опирается на традицию конверсационного анализа, с воодушевлением принимая его достижения в анализе ситуации «как она есть». В казарме смартфоны с камерой уже не редкость, они позволяют военнослужащим снимать повседневные практики, в том числе насильственного характера. Однако восприятие таких записей как механического слепка реальности будет ошибкой. Во многих случаях сам факт съемки становится контекстом, который определяет происходящее на записи. Например, распространенная в армии практика «похороны окурка» может быть организована так, чтобы записать ее на камеру в форме новостного репортажа. «Дед» ставит «слонам» задачу подмести плац, роняет фразу «прихожу и удивляюсь, как все чисто», уходит спать, возвращается и всетаки находит один окурок. По этому поводу «слоны» организуют «похороны» найденного окурка: «гробовщики» роют могилу, «оркестр» играет траурный марш, «священник» отпевает покойника, «родственники» рыдают. «Дед» с помощью камеры смартфона ведет прямой репортаж с места событий.

Характер съемки позволяет уяснить смысл происходящего, если исследователь имеет знание контекста. Например, видеозапись может открыто вестись из строя военнослужащих, по внешнему виду младшего призыва, которых «прокачивает» по внешнему виду «дед», вальяжно прохаживающийся перед строем. Если подходить к анализу видеозаписи механически, то можно сделать вывод о проявлении насилия старослужащего в отношении строя молодых. Однако сам ракурс съемки (изнутри строя) должен подсказывать, что запись ведется «дедом» на 50 дней до приказа ${ }^{1}$, в строю его товарищи по призыву, а перед строем разыгрывает представление один из «слонов». Трудно вообразить ситуацию, когда «слон» мог бы вести запись без риска быть жестоко наказанным, даже допустив, что он вообще имеет возможность пользоваться телефоном в этот период.

Видеозаписи являются ценным материалом для исследователя насилия. Однако вопрос заключается в том, как их анализировать: как нейтральную фиксацию «естественно» разворачивающихся практик (подход Коллинза) либо как часть того локального порядка, который запись фиксирует. В последнем случае факт съемки не следует рассматривать как нарушение некой первозданной «естественности» ситуации. Как отмечает

\footnotetext{
${ }^{1}$ В день, когда остается ровно пятьдесят дней до приказа («полтинник»), происходит инверсия: «слон» встает на место «деда», а «дед» на место «слона». «Слон» может делать все, что положено «деду»: в том числе, применять наказания, а «дед» в свою очередь обязан подчиняться. Единственным условием является соразмерность, т.е. нельзя превышать те пределы, за которые старались не выходить сами «деды». После того как этот день заканчивается, действует запрет на месть за все, что делали «слоны».
} 
Андрей Корбут, «[е]стественность естественна лишь для данной практики, и способность ее производить и опознавать в деталях действий составляет компетенцию носителей этой практики» (Корбут 2012: 160). Вытянутая вперед рука старослужащего, снимающая практики дедовщины на смартфон, создает и в то же время фиксирует локальную естественность «видеосъемки практик насилия». Практические цели этого могут быть разные - посмеяться потом с товарищами из других подразделений, забрать на «гражданку» как память, выложить на страницу «Вконтакте» с многозначительной подписью «кто служил, тот поймет». Так, съемка практик дедовщины сама может становиться практикой дедовщины.

\section{Заключение}

Понимание порядка в тотальном институте через выделение характеристик, которое предлагает Гоффман, имеет ограничения. Рассмотрение правил, времени и насилия как внешних параметров не учитывает способность обитателей тотальных институтов производить эти феномены в актуальных практиках. В конкретных ситуациях в казарме трудно разграничить феномены правил, времени и насилия, они связаны и определяются друг через друга. Проиллюстрируем этот вывод. Например, молодому родные собираются прислать в посылке какую-то вещь на день рождения, журнал или плеер. Тот идет договариваться со своим «дедом» о возможности иметь эту вещь, на что получает ответ в виде вопроса: «Уже положено?». В армии не существует закрытого перечня вещей, запрещенных к хранению молодыми, но есть общая интуиция, что молодой не должен радоваться или получать удовольствие («тащиться»). Своим вопросом-ответом с отсылкой ко времени дед заставляет самого молодого вывести правило дедовщины и опознать свою просьбу как его нарушение.

Время в свою очередь может определяться в разговоре через отсылку к практикам дедовщины: такое-то событие случилось «по духанке», «по черепянке». Насилие часто обосновывается дедами цикличностью процесса во времени: «станете дедами, сами поймете, что без этого здесь никак», т.е. смиряясь с насилием, молодой воспринимает его из перспективы себя в будущем. Так, социальный порядок в армии предстает не совокупностью характеристик, выделяемых социологом, но рефлексивной работой обитателей казармы по достижению осмысленности практик в контексте других практик. Подобная смысловая подвижность и гибкость дедовщины позволяет ей выживать, несмотря на все происходящие в армии институциальные изменения.

\section{Выражения благодарности}

Я признателен Отделу академического сотрудничества Посольства Франции в РФ, Campus France и Центру исследований общественных движений (EHESS, Париж) за предоставленную возможность собрать материал для французского кейса. 


\section{Список источников}

Банников К. (2002) Антропология экстремальных групп: Доминантные отношения среди военнослужащих срочной службы Российской Армии. М.: Институт этнологии и антропологии им. Н.Н. Миклухо-Маклая.

Волков В. (1997) О концепции практик(и) в социальных науках. Социологические исследования, (6): 9-23.

Ефимов А. (2005) 730 дней в сапогах. Дружба народов, (9). Доступно по ссылке: http:// magazines.russ.ru/druzhba/2005/9/e2.html (дата обращения: 6 августа 2018).

Корбут А. (2012) Видео социо. Социологическое обозрение, 11 (2): 143-153.

Лысенко О. (2012) «Дембель неизбежен, как крах капитализма». Неуставные отклонения от униформы в Советской армии 1970-1980-х годов. Теория моды, (26): 123-146.

Подрабинек К. (1991) Казармы в Туркмении. С. А. Белановский, С.Н. Марзеева (ред.) Дедовщина в армии: сборник сочиологических документов. М.: Институт народнохозяйственного прогнозирования: 195-211.

Пэнто Л. (2001) Личный опыт и научное требование объективности. Р. Ленуар, Д. Мерлье, Л. Пэнто, П. Шампань (ред.) Начала практической социологии. М.: Институт экспериментальной социологии: 24-77.

Указ Президента Российской Федерации (1993) Об утверждении общевоинских уставов Вооруженных Сил Российской Федерации № 2140 от 14.12.1993 г.

Хархордин О. (2008) В чем специфика исследования практик? В. В. Волков, О.В. Хархордин (ред.) Теория практик. СПб.: Издательство Европейского университета: 31-45. Чекунов В. (2008) Кирза. М.: Популярная литература.

Bessin M. (2002) Laisser passer le temps: Rites et rythmes de l'ennui. M. Bessin (ed.) Autopsie du service militaire 1965-2001. Paris: Autrement: 84-89.

Bozon M. (1981) Les Conscrits. Paris: Berger-Levrault.

Cassagne J. M. (2007) Le grand dictionnaire de l'argot militaire. Paris: Little Big Man.

Cernikova H. (2004) Time to Waste. The Journal of Power Institutions in Post-Soviet Societies, (1). Available at: http://journals.openedition.org/pipss/236 (accessed 6 August 2018).

Collins R. (2008) Violence. A Micro-Sociological Theory. Princeton, NJ: Princeton University Press.

Daunizeau F. (2002) Journal d'appelé (extraits). M. Bessin (ed.) Autopsie du service militaire 1965-2001. Paris: Autrement: 76-83.

Garfinkel H. (2002) Ethnomethodology's Program: Working Out Durkheim's Aphorism. Lanham, MD: Rowman \& Littlefield.

Goffman E. (1961) Asylums. New York: Anchor Books.

Goffman E. (1989) On Fieldwork. Journal of Contemporary Ethnography, (18): 123-132.

Human Rights Watch (2004) The Wrongs of Passage: Inhuman and Degrading Treatment of New Recruits in the Russian Armed Forces. Available at: https://www.hrw.org/report/2004/10/19/ wrongs-passage/inhuman-and-degrading-treatment-new-recruits-russian-armed-forces (accessed 6 August 2018).

Oleynik A. (2004) Dedovshchina as an Element of the 'Small Society': Evidence from Russia and Other Countries. The Journal of Power Institutions in Post-Soviet Societies, 1. Available at: http://journals.openedition.org/pipss/136 (accessed 6 August 2018).

Pennac D. (1973) Le service militaire au service de qui? Paris: Seuil.

Zerubavel E. (1985) Hidden Rhythms: Schedules and Calendars in Social Life. Berkeley: University of California Press.

Zurcher L. A. (1965) The Sailor Aboard Ship: A Study of Role Behavior in a Total Institution. Social Forces, 43 (3): 389-400. 
Timur Bocharov

\section{RULES, TIME AND VIOLENCE IN THE BARRACKS: THE LOGIC OF A TOTAL INSTITUTION IN TRANSITION}

This article analyses everyday life in the contemporary Russian army. Following Erving Goffman's theory of total institutions, researchers usually distinguish the characteristics of social order in the army in terms of dichotomy between formal and informal rules, the special organization of time, and high levels of violence. However, in contrast to this line of thought, here rules, time and violence in the army are viewed not as external predetermined characteristics, but as a result of the language practices and interpretations of the barracks' inhabitants. This dynamic perspective helps to understand why the phenomenon of dedovshchina is still important in the Russian army, despite changes to the institutional environment. In particular, the study demonstrates the intrinsic link between formal rules of military statutes and informal rules of dedovshchina, which in certain situations could be treated as two sides of the same coin. The article examines how modification of the statutory military uniform contributes to the construction of symbolic boundaries and the reproduction of status hierarchies in the army. Furthermore, the article describes soldiers' social practices, which allow time to materialize and convert it into a source of power. Finally, the article considers why some actions that could be treated as violent by outsiders are not recognised as such in the army. In addition, the article analyses the role of the smartphone video camera, which is gradually becoming a key attribute of army life, transforming the nature of barracks violence. The research is based on observations made during the military service and examines the narratives of ex-soldiers tell about their experience of military service. Additional information is also taken from army online forums. For a better understanding of the specific features of Russian dedovshchina, the article contains crosscultural comparisons with the seemingly similar phenomenon of bizutage that existed in the French conscript army.

Key words: total institution, army, dedovshchina, Erving Goffman, Eviatar Zerubavel, Randall Collins

DOI: 10.17323/727-0634-2019-17-3-359-374

\section{References}

Bannikov K. (2002) Antropologiya ekstremal'nykh grupp: Dominantnye otnosheniya sredi voennosluzhashchikh srochnoy sluzhby Rossiyskoy Armii [The Anthropology of Extreme Groups: Dominant Relations among Conscripts in the Russian Army]. Moscow: N.N. Miklukho-Maklai Institute of Ethnology and Anthropology.

Timur Bocharov - MA in Sociology (EUSP), LLM (Manchester), PhD Candidate (Kent); research fellow, Institute for the Rule of Law at the European University at Saint Petersburg, Russian Federation. Email: tbocharov@eu.spb.ru 
Bessin M. (2002) Laisser passer le temps: Rites et rythmes de l'ennui. In: M. Bessin (ed.) Autopsie du service militaire 1965-2001. Paris: Autrement: 84-89.

Bozon M. (1981) Les Conscrits. Paris: Berger-Levrault.

Cassagne J. M. (2007) Le grand dictionnaire de l'argot militaire. Paris: Little Big Man.

Cernikova H. (2004) Time to Waste. The Journal of Power Institutions in Post-Soviet Societies, 1. Available at: http://journals.openedition.org/pipss/236 (accessed 6 August 2018).

Chekunov V. (2008) Kirza [Kersey]. Moscow: Popular Literature.

Collins R. (2008) Violence. A Micro-Sociological Theory. Princeton, NJ: Princeton University Press.

Daunizeau F. (2002) Journal d'appelé (extraits). M. Bessin (ed.) Autopsie du service militaire 1965-2001. Paris: Autrement: 76-83.

Executive Order (Decree) of the President of the Russian Federation (1993) Ob utverzhdenii obshchevoinskikh ustavov Vooruzhennykh Sil Rossiyskoy Federatsii [On the Confirmation of Basic Military Regulations] № 2140 from 14 December 1993.

Efimov A. (2005) 730 dney v sapogakh [730 Days in Jackboots]. Druzhba narodov [Peoples' Friendship], 9. Available at: http://magazines.russ.ru/druzhba/2005/9/e2.html (accessed $6 \mathrm{Au}-$ gust 2018).

Garfinkel H. (2002) Ethnomethodology's Program: Working Out Durkheim's Aphorism. Lanham, MD: Rowman \& Littlefield.

Goffman E. (1961) Asylums. New York: Anchor Books.

Goffman E. (1989) On Fieldwork. Journal of Contemporary Ethnography, (18): 123-132.

Human Rights Watch (2004) The Wrongs of Passage: Inhuman and Degrading Treatment of New Recruits in the Russian Armed Forces. Available at: https:/www.hrw.org/report/2004/10/19/ wrongs-passage/inhuman-and-degrading-treatment-new-recruits-russian-armed-forces (accessed 6 August 2018).

Kharkhordin O. (2008) V chem spetsifika issledovaniya praktik? [What are the Specifics of Practices Research?]. V. V. Volkov, O. V. Kharkhordin (eds.) Teoriya praktik [Theory of Practices]. St. Petersburg: European University Press: 31-45.

Korbut A. (2012) Video sotsio [Video socio]. Sotsiologicheskoe obozrenie [Sociological Review], 11 (2): 143-153.

Lysenko O. (2012) 'Dembel' neizbezhen, kak krakh kapitalizma'. Neustavnye otklonenija ot uniformy v Sovetskoj armii 1970-1980-h godov ['Demobbing is as inevitable as the collapse of Capitalism'. Non-Statutory Divergences of the Uniform in the Soviet Army in 1970-1980]. Teoriya mody [Fashion Theory], (26): 123-146.

Oleynik A. (2004) Dedovshchina as an Element of the 'Small Society': Evidence from Russia and Other Countries. The Journal of Power Institutions in Post-Soviet Societies, 1. Available at: http://journals.openedition.org/pipss/136 (accessed 6 August 2018). 
Pennac D. (1973) Le service militaire au service de qui? Paris: Seuil.

Pinto L. (2001) Lichnyy opyt i nauchnoe trebovanie ob"ektivnosti [Personal Experience and Scientific Requirement of Objectivity]. P. Champagne, R. Lenoir, D. Merllié, L. Pinto (ed.) Nachala prakticheskoy sotsiologii [The Fundamentals of Practical Sociology]. Moscow: Institute of Experimental Sociology:24-77.

Podrabinek K. (1991) Kazarmy v Turkmenii [Barracks in Turkmenia]. S. A. Belanovskiy, S. N. Marzeeva (eds.) Dedovshchina v armii: sbornik sotsiologicheskikh dokumentov [Dedovschina in the Army: A Collection of Sociological Documents]. Moscow: Institute of Economic Forecasting of the Russian Academy of Sciences: 195-211.

Volkov V. (1997) O kontseptsii praktik(i) v sotsial'nykh naukakh [On the Concept of Practice(s) in the Social Sciences]. Sotsiologicheskie issledovaniya [Sociological Research], 6:9-23.

Zerubavel E. (1985) Hidden Rhythms: Schedules and Calendars in Social Life. Berkeley: University of California Press.

Zurcher L.A. (1965) The Sailor Aboard Ship: A Study of Role Behavior in a Total Institution. Social Forces, 43 (3): 389-400. 